\title{
Erratum: Correction of Figure
}

\section{현사시나무에서 Dormancy-associated protein 1 (DRM1) 유전자의 분리와 발현 륵성 구명}

윤서경 ${ }^{1,2}$ - 배은경 ${ }^{1}$ 최현모 ${ }^{1}$ · 최영임 ${ }^{1} \cdot$ 이효신 ${ }^{1}$ *

'국립산림과학원 산림유전자원부, ${ }^{2}$ 서울대학교 산림과학부

\section{Isolation and Expression of Dormancy-associated protein 1 (DRMI) in Poplar (Populus alba $\times$ P. glandulosa)}

\author{
Seo-Kyung Yoon ${ }^{1,2} \cdot$ Eun-Kyung Bae ${ }^{1} \cdot$ Hyunmo Choi $^{1} \cdot$ Young-Im Choi $^{1} \cdot$ Hyoshin Lee $^{1}$ * \\ ${ }^{1}$ Department of Forest Sciences, Seoul National University, 1 Gwanak-ro, Seoul 08826, Republic of Korea, \\ ${ }^{2}$ Department of Forest Genetic Resources, National Institute of Forest Science, 39 Onjeong-ro, Suwon 16631, Republic of Korea
}

To the Editor:

We found an error in our published article.

Seo-Kyung Yoon, Eun-Kyung Bae, Hyunmo Choi, Young-Im Choi, and Hyoshin Lee Isolation and Expression of Dormancy-associated protein 1 (DRM1) in Poplar (Populus alba $\times$ P. glandulosa). J Plant Biotechnol 2017;44:69-75, https://doi.org/10.5010/JPB.2017.44.1.069

The legends of Fig. 2 were marked incorrectly. The correct legends are below.

Corrected Fig. 2
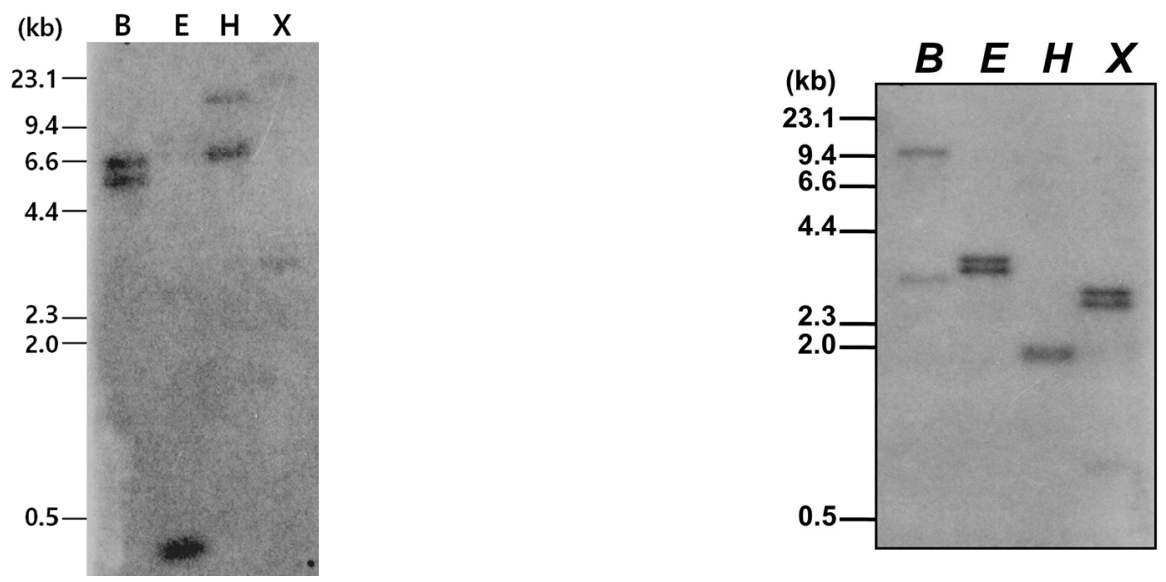

(C) Korean Society for Plant Biotechnology 